\title{
Efek Latihan Kegel pada Kekuatan Otot Dasar Panggul Ibu Pasca Persalinan
}

\section{The Effect of Kegel Exercise on Pelvic Floor Muscle Strength in Post Delivery Mother}

\author{
Rahajeng \\ Divisi Uroginekologi Laboratorium Obstetri dan Ginekologi Rumah Sakit Umum Dr. Saiful Anwar Malang
}

\begin{abstract}
ABSTRAK
Kehamilan dan persalinan menyebabkan perubahan mekanik dan denervasi otot-otot dasar panggul yang menimbulkan keluhan stres inkotinensia, prolaps organ panggul dan gangguan seksual sehingga menurunkan kualitas hidup pasien. Penelitian ini dilakukan untuk mengetahui efek latihan otot dasar panggul pada kekuatan otot dasar panggul. Desain randomized clinical trial dilakukan pada ibu 4 minggu pasca persalinan pervaginam yang memenuhi kriteria inklusi dan eksklusi. Pada kelompok eksperimen dilatih untuk melakukan latihan otot dasar panggul, sehingga mereka dapat melakukan latihan otot dasar panggul di rumah. Evaluasi kontraksi otot dasar panggul dengan perineometer dilakukan diawal dan setiap 4 minggu sekali selama 12 minggu. Perbedaan kekuatan otot dasar panggul pada setiap kelompok dianalisis dengan paired $t$ test, sedangkan perbedaan antar kelompok diuji dengan unpaired t test. Pada kelompok kontrol tidak didapatkan perbedaan kekuatan otot panggul sesudah 4-12 minggu bila dibandingkan kondisi awal (44.4), sebaliknya pada kelompok perlakuan didapatkan perbedaan bermakna. Hasil uji independent sample $t$ test menunjukkan perubahan otot dasar panggul sesudah 12 minggu pada kelompok perlakuan lebih tinggi secara bermakna dibandingkan kontrol. Penelitian ini membuktikan latihan otot dasaar panggul secara mandiri memberikan perbaikan kekuatan otot dasar panggul sejak 4 minggu pertama hingga 12 minggu.
\end{abstract}

Kata Kunci : Kekuatan otot dasar panggul, senam kegel, postportum

\begin{abstract}
Pregnancy and delivery process will influence mechanical change and denervasi pelvic floor muscle that might lead to psychological stress, incontinentia uri, pelvic organ prolapse resulted in reducing quality of life. This research aimed to measure the effect of kegel exercise in pelvic floor muscle strength. A randomized clinical trial was performed every 4 weeks up to 12 weeks after vaginal delivery divided in control group without exercise and treatment group with routine Kegel exercise. The treatment group was trained in order to be able to perform regular Kegel exercise at home. Pelvic floor muscle strength were measured using perineometer. The data were analyzed using paired and unpaired t test to measure the differences. In control group there is no significant differences of pelvic floor strength after 4-12 minggu compared to first measurement (44.4), but in treatment group we identify significant differences. T-test independent show significant change in pelvic floor strength after 12 weeks compared ti control group. It can be concluded that Kegel exercise has significant effedt in improving pelvic floor strength since the first 4 weeks after delivery until 12 weeks.
\end{abstract}

Keywords : Kegel exercise, pelvic floor strength, pregnancy

Jurnal Kedokteran Brawijaya Vol. 26, No. 2, Agustus 2010; Korespondensi: Rahajeng. Divisi Uroginekologi, Laboratorium Obstetri dan Ginekologi, Rumah Sakit Umum Dr. Saiful Anwar Malang, Jl. Jaksa Agung Suprapto 2A Malang Tel. (0341) 335979 Email: jen_urogyn@yahoo.co.id 


\section{PENDAHULUAN}

Latihan otot dasar panggul yang pertama kali dikembangkan tahun 1940 oleh Dr. Arnold Kegel untuk mengatasi stres inkontinensia, dapat digunakan untuk menguatkan otot dasar panggul (1). Latihan tersebut berupa latihan otot dasar panggul secara progresif pada otot levator ani yang bekerja dibawah kontrol yang selanjutnya dikenal sebagai Kegel exercise. Latihan ini berhubungan dengan berbagai perubahan yang terjadi pada kekuatan otot dasar panggul seperti sphincter uretra dan sphincter anal. Proses ini dapat meningkatkan tekanan atau tahanan untuk menutup uretra sehingga dapat mencegah pengeluaran urin di luar kontrol (2). Keistimewaan latihan ini adalah sangat mudah dalam pelaksanaanya, tidak memerlukan ruang yang luas, dapat dilakukan dalam berbagai posisi, saat perjalanan, bekerja atau istirahat. Kegel exercise sering dikombinasi dengan teknik biofeedback dengan tujuan untuk memperoleh hasil yang lebih baik. Teknik biofeedback dapat merubah suatu kejadian kedalam bentuk signal visual ataupun auditori kemudian signal ini dikembalikan kepada pasien. Dengan teknik biofeedback pasien dapat belajar bagaimana cara memanipulasi dan mengembalikan pada keadaan fisiologis dalam tubuhnya sendiri $(2,3)$. Tingkat keberhasilan yang dilaporkan dari latihan otot dasar panggul berbeda-beda antara 40 sampai $90 \%$. Hasil latihan tergantung kepada populasi studi dan kriteria penilaian keberhasilan. Beberapa studi menggunakan penilaian subjektif. Kriteria penilaian objektif umum meliputi tes otot manual dengan palpasi vagina, manometri, dinamometri, dan cone. Dalam satu studi dengan menggunakan penilaian subjektif, melaporkan $84 \%$ mengalami perbaikan inkontinensia dengan latihan otot dasar panggul. Henalla, dalam penilaian objektif melaporkan bahwa $67 \%$ dari pasien yang mengalami inkontinensia akan mengalami perbaikan dengan latihan otot dasar panggul (3). Lanson menunjukkan bahwa program latihan otot dasar panggul postpartum dapat mengurangi secara signifikan prevalensi inkontinensia urin setelah persalinan.

Masih terbatas penelitian yang menguji efek langsung pada perbaikan kekuatan otot dasar panggul secara terukur. Penelitian ini dilakukan untuk efek latihan otot dasar panggul pada kekuatan otot dasar panggul pada ibu pascapersalinan. Terdapat beberapa pilihan alat untuk mengukur kekuatan otot dasar panggul tetapi pada penelitian ini digunakan perineometer. Kelebihan perineometer adalah harganya relatif tidak mahal, mudah dibawa, mampu untuk mengukur kekuatan dan ketahanan secara objektif dalam satuan $\mathrm{cmH}_{2} \mathrm{O}$ dan bisa digunakan dalam posisi berdiri $(4,5)$.

\section{METODE}

Penelitian dilakukan dengan rancangan randomized clinical trial, pada dua kelompok kontrol dan perlakuan. Pre test di lakukan pada kedua kelompok menggunakan perineometer Peritron dan evaluasi dilakukan setiap 4 minggu hingga 12 minggu. Subjek pada penelitian ini adalah pasien pasca persalinan pervaginam setelah masa nifas (4 minggu pasca persalinan) yang datang ke poli nifas RSU Dr. Saiful Anwar Malang. Pada kelompok perlakuan diberikan pelatihan sehingga mampu melakukan latihan otot dasar panggul secara mandiri dirumah.

Untuk mengendalikan bias dilakukan evaluasi usia, status gizi dengan indikator BMI, tekanan darah diukur dalam
Mean Arterial Pressure (MAP), dan status paritas atau jumlah anak sebagai faktor yang dapat mempengaruhi kekuatan otot dasar panggul. Untuk menganalisis perbedaan kekuatan kontraksi otot dasar panggul sesudah melakukan latihan, digunakan uji $t$ berpasangan. Perbedaan kekuatan kontraksi otot dasar panggul antar kelompok digunakan uji $t$ tidak berpasangan.

\section{HASIL}

Analisis deskriptif ini dimaksudkan untuk menggambarkan distribusi dari karakteristik atau demografi subjek. Berdasarkan hasil penelitian, diperoleh informasi mengenai karakteristik para subjek berupa usia, BMI, MAP dan paritas mereka. Gambaran karakteristik responden menunjukkan tidak ada perbedaan bermakna pada kedua kelompok (Tabel 1).

Tabel 1. Gambaran usia, BMI, MAP dan paritas pada kedua kelompok.

\begin{tabular}{|c|c|c|c|}
\hline \multirow{2}{*}{ Karakteristik } & \multicolumn{2}{|c|}{ Nilai Rerata (mean SD) } & \multirow{2}{*}{$p$} \\
\hline & Tanpa Latihan & Dengan Latihan & \\
\hline Usia (tahun) & $29.13 \pm 5.53$ & $29.53 \pm 5.11$ & 0.838 \\
\hline BMI (kg/m2) & $25.05 \pm 2.61$ & $24.31 \pm 2.94$ & 0.472 \\
\hline $\mathrm{MAP}(\mathrm{mmHg})$ & $86.40 \pm 5.36$ & $88.47 \pm 3.93$ & 0.238 \\
\hline Prosentase & $1.33 \pm 0.49$ & $1.27 \pm 0.59$ & 0.739 \\
\hline - 1 anak & $10 \quad(66.7 \%)$ & $12 \quad(80.0 \%)$ & \\
\hline - 2 anak & (33.3\%) & $(13.3 \%)$ & \\
\hline - 3 anak & $(0.0 \%)$ & $(6.7 \%)$ & \\
\hline
\end{tabular}

Hasil penelitian menunjukkan pada kelompok kontrol cenderung tidak menunjukkan perubahan kekuatan otot dasar panggul dibandingkan kondisi awal pada evaluasi empat minggu pertama $\left(\mathrm{cmH}_{2} \mathrm{O}\right)$ hingga minggu kedua belas $\left(\mathrm{cmH}_{2} \mathrm{O}\right)$. Uji juga menunjukkan tidak ada perbedaan bermakna kekuatan otot pangggul sesudah 4 hingga 12 minggu pada kelompok yang tidak melakukan latihan otot dasar panggul. Sebaliknya pada kelompok yang melakukan pelatihan didapatkan perubahan bermakna kekuatan otot dasar panggul empat hingga 12 minggu sesudah pelatihan.

Tabel 2. Kekuatan otot dasar pinggul

\begin{tabular}{lccc}
\hline Waktu & Kontrol & Perlakuan & $\mathrm{p}$ \\
\hline Awal & $44.4(13.18)$ & $31.5(8.89)$ & \\
4 Minggu & $44.2(13.03)$ & $41.3(8.83)$ & 0.731 \\
8 Minggu & $44.87(12.25)$ & $50.3(7.35)$ & 0.618 \\
12 Minggu & $45.33(14.06)$ & $58.7(8.54)$ & 0.164 \\
\hline
\end{tabular}

Sesudah dilakukan uji normalitas menggunakan Kolmogorov Smirnov $(p=0.2)$, dilakukan uji $t$ independent perbedaan selisih kekuatan otot dasar panggul sesudah 12 minggu pada kedua kelompok. Kelompok perlakuan menunjukkan peningkatan kekuatan otot panggul yang lebih tinggi (rerata=0.93 $\mathrm{cmH}_{2} \mathrm{O} ; \mathrm{Cl} 95 \%$ : 0.4307-2.2973) secara bermakna $(\mathrm{t}=7.826 ; 0<0.001)$ dibandingkan kelompok kontrol (rerata $=27.27 \mathrm{cmH}_{2} \mathrm{O} ; \mathrm{Cl} 95 \%$ : 20.179534.3538). 


\section{PEMBAHASAN}

Kekuatan otot dasar panggul dipengaruhi beberapa faktor yang melekat pada ibu diantaranya usia, paritas. Beberapa penelitian tentang prolapsus uterus akibat kelemahan otot dasar panggul menunjukkan peningkatan prevalensi berhubungan dengan bertambahnya usia. Swift pada penelitiannya membandingkan 368 wanita sebagai kontrol dengan 87 wanita dengan prolapsus uterus berat. Hasil penelitian menunjukkan bahwa penambahan usia bersama-sama dengan penambahan berat badan bayi lahir pervaginam, riwayat histerektomi dan riwayat operasi sebelumnya merupakan faktor etiologi terbanyak pada prolapsus uterus berat yang dianalisa secara regresi logistik multiple (4). Clark dan kawan-kawan meneliti hewan dengan faktor-faktor resiko yang umumnya terdapat pada manusia, yaitu usia, paritas, jaringan penyangga, tingkatan prolapsus. Efek dari penuaan maupun menurunnya estrogen sulit untuk dipisahkan karena keduanya muncul pada saat yang bersamaan $(4,5)$. Berdasarkan data karakteristik sampel menunjukkan bahwa usia ibu pasca persalinan pada subjek penelitian yang tidak mendapat latihan otot dasar panggul rata-rata 29.13 tahun ( \pm SD 5.53), sedangkan pada ibu pascapersalinan yang mendapat latihan otot dasar panggul rata-rata 29.53 tahun ( \pm SD 5.11) menunjukkan tidak ada perbedaan bermakna pada kedua kelompok pada aspek usia.

Hasil analisa statistik menunjukkan bahwa rata-rata hasil pengukuran kekuatan otot dasar panggul pada ibu pascapersalinan yang tidak mendapat latihan otot dasar panggul pada evaluasi awal sebesar 44.40 (SD \pm 13.18 $\mathrm{CmH}_{2} \mathrm{O}$ ) dan cenderung tetap hingga evaluasi III sebesar 45.33 ( $\mathrm{SD} \pm 14.06) \mathrm{cmH}_{2} \mathrm{O}$. Secara statistik tidak ditemukan perbedaan bermakna kekuatan otot dasar panggul pada ibu yang tidak mendapat latihan selama empat bulan evaluasi. Otot dasar panggul dapat melemah akibat kerusakan jaringan penghubung sewaktu persalinan pervaginam kanker. Tanpa latihan otot dasar panggul tidak akan ada perbaikan kekuatan otot dasar panggul (5). Kelemahan otot-otot dasar panggul dapat menyebabkan gagalnya otot tersebut menjalankan fungsinya. Berbagai keluhan yang terjadi akibat keadaan tersebut antara lain stres inkotinensia, prolapsus organ panggul dan gangguan seksual, yang tentu saja semuanya akan menurunkan kualitas hidup pasien (1).

Hasil analisa menunjukkan terdapat perbaikan bermakna kekuatan otot panggul ibu selama empat bulan evaluasi dengan pelatihan otot dasar panggul. Pada awal didapatkan kekuatan sebesar $31.5(\mathrm{SD} \pm 8.89) \mathrm{cmH}_{2} 0$, pada evaluasi I (perlakuan I) sebesar $41.3(\mathrm{SD} \pm 8.83) \mathrm{cmH}_{2} \mathrm{O}$ dan pada evaluasi III sebesar 58.7 (SD \pm 8.54$) \mathrm{cmH}_{2} \mathrm{O}$. Kondisi ini menunjukkan bahwa kekuatan otot dasar panggul pada ibu pasca persalinan pada saat pada evaluasi awal jika dibandingkan dengan saat setelah mendapat latihan otot dasar panggul baik pada evaluasi I, II dan III menunjukkan adanya perbedaan hasil pengukuran yang cukup besar. Hal ini disebabkan program latihan otot dasar panggul secara progresif pada otot levator ani yang bekerja dibawah kontrol. Latihan otot dasar panggul ini merupakan bentuk penguatan kelompok otot dasar panggul, sehingga berhubungan dengan berbagai perubahan yang terjadi pada kekuatan otot dasar panggul seperti sphincter uretra dan sphincter anal. Latihan otot dasar panggul ini dapat meningkatkan tekanan atau tahanan untuk menutup uretra, sehingga dapat mencegah pengeluaran urin di luar kontrol (2). Hal ini sesuai dengan penelitian objektif yang pernah dilakukan bahwa $67 \%$ dari pasien yang mengalami inkontinensia akan mengalami perbaikan dengan latihan otot dasar panggul (3).

Berdasarkan hasil uji independent sampel $t$ test menunjukkan bahwa pada ibu pascapersalinan yang mendapat latihan otot dasar panggul cenderung mempunyai selisih pengukuran kekuatan otot dasar panggul pre dan post test (mean $=27.27 \mathrm{cmH}_{2} \mathrm{O}$ ) yang lebih tinggi (mean=0.93 $\mathrm{cmH}_{2} \mathrm{O}$ ). Kondisi ini dapat dipahami, karena dengan adanya latihan otot dasar panggul pada kelompok perlakuan dapat menyebabkan kekuatan otot dasar panggul menjadi lebih tinggi dibandingkan dengan kelompok para ibu yang tidak melakukan latihan otot dasar panggul. Penelitian Markved menemukan perbaikan yang lebih besar secara signifikan pada kekuatan otot dasar panggul antara tes 1 dan tes 2 pada kelompok yang diberikan latihan dibandingkan dengan kelompok kontrol $(6,7)$. Latihan otot dasar panggul yang dirancang secara khusus, efektif dalam meningkatkan kekuatan otot dasar panggul dan mengurangi inkontinensia urin pada periode post partum $(6,7)$

Menurut Meyer et al (2001), latihan otot dasar panggul merupakan latihan penguatan isometrik terhadap otot-otot dasar panggul dengan tujuan agar dapat melawan penurunan organ panggul, dan mengembalikan hubungan anatomis antara organ-organ panggul seperti semula, serta menjaga keseimbangan otot-otot abdominal, punggung dan kuadran bawah yang vital untuk melakukan program rehabilitasi. Sasaran dari latihan otot dasar panggul ini untuk melawan berbagai penurunan dari organ pelvis, serta mengembalikan hubungan anatomi yang normal dari struktur organ pelvis $(8,9)$. Seperti telah diketahui bahwa otot-otot dasar panggul kekuatannya menurun pasca persalinan pervaginam, dan bertambah menurun secara kumulatif dengan bertambahnya paritas.

Jika ditinjau berdasarkan selisih pengukuran kekuatan otot dasar panggul pre test (evaluasi awal atau ke-0) dan post test (evaluasi terakhir atau ke-3) menunjukkan bahwa latihan otot dasar panggul berpengaruh terhadap selisih pengukuran kekuatan otot dasar panggul pre dan post test pada ibu pasca persalinan hingga 68.6\%. Latihan otot dasar panggul akan meningkatkan selisih pengukuran kekuatan otot dasar panggul pre dan posttest pada ibu pascapersalinan hingga $26.33 \mathrm{cmH}_{2} \mathrm{O}$. Dapat diartikan bahwa semakin banyak dilakukan latihan otot dasar panggul, maka akan berpengaruh signifikan dalam meningkatkan selisih pengukuran kekuatan otot dasar panggul pre dan post test pada ibu paska persalinan (perlakuan), dibandingkan selisih pengukuran kekuatan otot dasar panggul pre dan post test pada ibu pascapersalinan yang tidak melakukan latihan otot dasar panggul. Besarnya pengaruh disini sudah dapat mengukur besar pengaruh secara keseluruhan dari pemberian latihan otot dasar panggul terhadap kekuatan otot dasar panggul baik pada ibu pasca persalinan yang mendapat latihan otot dasar panggul dan yang tidak mendapat latihan otot dasar panggul, karena telah mempertimbangkan kondisi kekuatan otot dasar panggul pada saat sebelum dilakukan latihan otot dasar panggul.

Selisih pengukuran kekuatan otot dasar panggul pre test (evaluasi awal atau ke-0) dan post test (evaluasi terakhir 
atau ke-3) menunjukkan bahwa latihan otot dasar panggul berpengaruh terhadap selisih pengukuran kekuatan otot dasar panggul pre dan post test pada ibu pasca persalinan hingga $68.6 \%$. Latihan otot dasar panggul akan meningkatkan selisih pengukuran kekuatan otot dasar panggul pre dan post test pada ibu pasca persalinan hingga $26.33 \mathrm{cmH}_{2} \mathrm{O}$. Dapat diartikan bahwa semakin banyak dilakukan latihan otot dasar panggul, maka akan berpengaruh signifikan dalam meningkatkan selisih pengukuran kekuatan otot dasar panggul pre dan post test pada ibu pasca persalinan (perlakuan), dibandingkan selisih pengukuran kekuatan otot dasar panggul pre dan post test pada ibu pasca persalinan yang tidak melakukan latihan otot dasar panggul. Besarnya pengaruh disini sudah dapat mengukur besar pengaruh secara keseluruhan dari pemberian latihan otot dasar panggul terhadap kekuatan otot dasar panggul baik pada ibu pasca persalinan yang mendapat latihan otot dasar panggul dan yang tidak mendapat latihan otot dasar panggul, karena telah mempertimbangkan kondisi kekuatan otot dasar panggul pada saat sebelum dilakukan latihan otot dasar panggul

Latihan otot dasar panggul aman dilakukan oleh perempuan pasca persalinan pervaginam dan dapat dilakukan sesegera mungkin pada saat seorang perempuan baru melahirkan, setelah perempuan tersebut merasa sanggup untuk melakukannya. Pemberian latihan penguatan ini pada perempuan baru melahirkan sangat menguntungkan karena dapat meningkatkan sirkulasi dan mempercepat penyembahan luka. Latihan otot dasar panggul, dapat melatih otot dasar panggul kembali sehingga menjadi bertambah volumenya dan dapat kembali berfungsi normal (10). Sasaran latihan ini adalah menguatkan dua bentuk kelompok otot yang melintang pada dasar panggul yaitu kelompok yang

\section{DAFTAR PUSTAKA}

1. Lanson-Meyer DE. Effect of Postpartum Exercise on Mother and Their Off Spring: A Review of Literature. Obesity Research. 2002; 10(8): 841-853.

2. Meyer S, Hohlfeld P, Achtari C, and De Grandi P. Pelvic Floor Education after Vaginal Delivery. Obstetrics \& Gynecology. 2001; 97(5 Pt 1): 673-677.

3. Rao SSC. Pelvic Floor Dysfunction. Revista de Gastroenterologia de Mexico. 2010; 2(75); 72-82.

4. Swift S, Woodman P, O`Boyle A, et al. Pelvic Organ Support Study (POSST): The Distribution, Clinical Definition, and Epidemiologic Condition of Pelvic Organ Support Defects. American Journal of Obstetric \& Gynecolology. 2005; 192: 795-806.

5. Hughes D. Pelvic Organ Prolapse. In: Shcorge JO, et al. Williams Gynecology. New York: Mc-Graw Hill Medical; 2010; p. 1066-1070.

6. Markved S and Bo K. The Effect of Postpartum Pelvic Floor Muscle Exercise in the Prevention and Treatment of Urinary Incontinence. International berbentuk ayunan dan menyilang. Diharapkan dengan latihan tersebut, terjadi peningkatan volume otot dan penguatan refleks kontraksi saat terjadi peningkatan tekanan intra abdominal yang mendadak $(1,2,6,7)$. Wanita dengan kekuatan otot dasar panggul awal yang lebih lemah dan gejala yang lebih parah akan mengalami peningkatan presentasi kesembuhan yang lebih besar dengan melakukan latihan otot dasar panggul (11). Latihan otot dasar panggul sangat penting untuk mengembalikan tonus otot dasar panggul saat istirahat dan memaksimalkan kekuatan kontraksi otot dasar panggul, meningkatkan durasi kekuatan, dan meningkatkan waktu dan koordinasi kontraksi. Waktu untuk melakukan evalusi bervariasi antara satu peneliti dengan peneliti lainnya, kebanyakan peneliti melakukan evaluasi paling sedikit dalam waktu 4-12 minggu setelah diberikannya suatu terapi latihan $(10,11)$.

Program latihan otot dasar panggul postpartum dapat mengurangi secara signifikan prevalensi inkontinensia urin setelah persalinan (6). Tingkat keberhasilan latihan otot dasar panggul secara signifikan lebih tinggi pada pasien yang menerima latihan otot dasar panggul dengan fisioterapis di rumah sakit dibandingkan dengan melakukan latihan sendiri di rumah setelah diberi lembaran instruksi. Keberhasilan didapatkan pada mereka yang mempunyai motivasi bagus, relatif muda dengan tekanan penutupan urethra maksimum awal lebih tinggi, mempunyai durasi singkat dan tingkat stress incontinence yang lebih kecil serta melakukan latihan dengan benar. Sepertiga perempuan yang melakukan latihan otot dasar panggul tidak tahu bagaimana untuk melakukan kontraksi pada otot dasar panggul mereka. Oleh karena itu instruksi yang tepat, penilaian dan motivasi adalah penting bagi program latihan otot dasar panggul (12).

Urogynecology Journal and Pelvic Floor Disfunction. 1997; 84(4): 217-222.

7. Bols EM, Berghmans BC, Hendriks EJ, et al. A Randomized Physiotherapy Trial in Patients with Fecal Incontinence. BMC Public Health. 2007; 7: 355

8. Hibbard BM. Principles of Obstetrics. 1st edition. London: Butterworths and Co; 1987; p. 342-343.

9. Konkler CJ. Principles of Exercise for the Obstetric Patient. In: Kisner C, Colby LA. Therapeutic Exercise. 2nd edition. Singapore: Info Acces and Distribution; 1991; p. 547-576.

10. Sandvik H. 1996. Treatment of Female Urinary Incontinence-an Annotated Evaluation of Non Surgical Therapeutic Options. (Online) 16 March 1996. http://www.uib.no/isf/people/inkter.htm

12. Neumann P, Grimmer KA, and Deenadayalan Y. Pelvic Floor Muscle Training and Adjunctive Therapies for the Treatment of Stress Urinary Incontinence in Women. BMC Women's Health. 2006; 6: 11. 